\title{
Effect of gamma irradiation on beef quality
}

\author{
H. M. Mohamed 1 , M. M. T. Emara' 1 , M. D. H. Farag' , F. A. Elnawawi ${ }^{1}$ \\ ${ }^{I}$ Food Hygiene and Control Department, Faculty of Veterinary Medicine, Cairo University, Giza, Egypt \\ ${ }^{2}$ Food Irradiation Research Department, National Center for Radiation Research and Technology, Cairo, Egypt
}

Beef longissimus dorsi steaks were treated with 10, 25, and 50-kGy gamma irradiation and weekly examined during refrigeration storage at $5^{\circ} \mathrm{C}$ to evaluate the changes in their organoleptic, bacteriological, chemical and nutritional quality characteristics as well as deterioration criteria. The signs of spoilage became apparent after 17 days of refrigeration storage in control untreated samples compared with 52 days for $10 \mathrm{kGy}$ treated samples; however, samples treated with 25 or $50 \mathrm{kGy}$ remained without signs of spoilage until the end of storage period (4 months). A characteristic burnt flavor was distinguished in irradiated beef samples, which was intensified with high irradiation dose, but decreased during storage. High doses of irradiation especially $50 \mathrm{kGy}$ resulted in a brownish color of meat surface. Moreover, gamma irradiation resulted in high thiobarbituric acid values after treatments and during storage due to lipid oxidation. Thiamin content of beef was severely reduced and the reduction was dependant on the irradiation dose. Riboflavin was also affected by irradiation, but it was much stable than thiamin. The proximate chemical composition of beef was slightly affected by irradiation.

Consumers require high quality and safe meat that has fresh appearance, natural flavor and taste. Therefore, there is an interest by industry for new non-thermal technologies, which can inactivate both pathogenic and spoilage causing microorganisms while keeping the meat quality.

Food irradiation is a physical process involves direct exposure to ionizing radiations (Urbain, 1986). Irradiation of meat can provide several benefits; it improves the safety of fresh meats by reducing and/or eliminating food borne pathogens, and extends the shelf life of meat during refrigeration storage or produce shelf stable products without deterioration of its nutritive and sensory qualities (Thayer, 1993 and Fu et al., 1995a).

The joint FAO/IAEA/WHO Expert Committee (1981) reported that irradiation of any food commodity with up to $10-\mathrm{KGy}$ presents no toxicological hazards. It introduces no nutritional or microbiological problems. They added that further studies on high doses are required. Currently more than 26 countries used food irradiation on a commercial scale (Stevenson, 1994). With the exception of irradiation of spices and dried vegetables, which is widespread, other applications of this technology remain marginal. Therefore, the present study was conducted to evaluate the changes in different meat quality characteristics (sensory, chemically and bacteriologically) due to use of different doses of gamma radiation.

\section{Material and Methods}

Samples. Eighty beef $L$. dorsi muscle samples at the $11-13^{\text {th }}$ rib were collected as soon as possible after slaughter, and then rapidly transported to the laboratory in polyethylene bags surrounded by ice in order to minimize the chemical changes. In the laboratory, the external fascia and visible fat were removed, then each muscle sample was cut into steaks of about $100 \mathrm{~g}$ weights and $\sim 3 \mathrm{~cm}$ thickness. The samples were packed in polyethylene bags of about $0.03 \mathrm{~mm}$ thickness and about $20 \mathrm{~cm}$ long x $15 \mathrm{~cm}$ wide. The polyethylene bags containing steaks were heat sealed, and then frozen at $-40^{\circ} \mathrm{C}$ for $24 \mathrm{~h}$ before the different treatments.

Irradiation process and storage. Packed frozen beef steaks were transported to the National Center for Radiation Research and Technology (NCRRT) at Nasr city, Cairo, where the radiation treatments were applied using the Egypt Mega Unit "J-6500 Co ${ }^{60}$ ". The J-6500 machine is designed to irradiate the samples in boxes of 38.1 to $48.2 \mathrm{~cm}$ width, $91.4 \mathrm{~cm}$ height and 40.6 to $58.4 \mathrm{~cm}$ length. The dose rate being $1.50 \mathrm{kGy} / \mathrm{h}$ in the center of the irradiation box. The used irradiation doses in this study were 10 , 25 and $50-\mathrm{kGy}$. Irradiated and non-irradiated packed steaks were stored in the refrigerator at $5^{\circ} \mathrm{C}$ and samples were weekly subjected for the following analysis: 
Laboratory analysis.

Organoleptic evaluation. Irradiation flavor scores were recorded using 5-point hedonic scale described by (Sudarmadji and Urbain, 1972) with 1 indicates no irradiation flavor and 5 very strong irradiation flavor. The texture, color and off-odor scores were recorded using 5-point hedonic scale described by (Abu-Tarboush et al., 1997) where 1 and 5 indicate unacceptable and acceptable score respectively.

Bacteriological examination. Sample homogenate was prepared by homogenizing ten grams in $90 \mathrm{ml}$ of $0.1 \%$ peptone water for $1.5 \mathrm{~min}$. using lab blender and appropriate decimal dilutions were prepared in peptone water (APHA, 1992). Microbial populations were estimated as follows: colony forming units of aerobic mesophiles at $35^{\circ} \mathrm{C}$ (Swanson et al., 1992), anaerobic count (Lake et al., 1992), mesophilic aerobic sporeformers (Stevenson and Segner, 1992), Pseudomonas count (Kielwein, 1969), psychrotropic bacteria at $7^{\circ} \mathrm{C}$ (Cousin et al., 1992) and lipolytic bacteria (Smith and Hass, 1992).

Chemical analysis. Both irradiated and nonirradiated beef samples were analyzed for its proximate chemical analysis according to (Ronald and Ronald, 1991). Thiamin and riboflavin content according to (Chase et al., 1993). Moreover, deterioration criteria $(\mathrm{pH}$ value, thiobarbituric acid value and total volatile bases nitrogen) were assessed according to (FAO 1986).

\section{Results and discussion}

The data illustrated in Fig. (1A) and Table (1) clearly declared that irradiation developed a characteristic burnet flavor. The intensity of such flavor increased as the irradiation dose increased, with 25 and 50-kGy resulted in very strong irradiation flavor. However, the irradiation flavor scores were decreased during refrigeration storage at $5^{\circ} \mathrm{C}$. In this regard, Ahn et al. (2001) attributed the reduction in the intensity of the irradiation flavor scores to the volatization of the sulfur-containing compounds, responsible for most of the irradiation off-flavor, during aerobic storage. Irradiation flavor of foods are owing to the generation of volatile compounds from lipids and protein precursors produced by the radiolysis of water (Simic, 1983). Development of irradiation flavor in meat can be attributed to the oxidation of polyunsaturated fatty acids (Giroux and Lacroix, 1998), and/or the destruction of the antioxidants in muscle by the free radicals generated by irradiation (Thayer et al. 1993 and Lakritz et al., 1995).

Irradiation resulted in dose dependent decrease in the color scores of beef with samples treated with 10-kGy remained acceptable throughout 45 days of storage at $5^{\circ} \mathrm{C}$. Moreover, irradiation at 25 and $50 \mathrm{kGy}$ resulted in a more decrease in color scores, with the color scores remained within the organoleptically acceptable limit for 4 months of refrigeration storage in samples irradiated with $25 \mathrm{kGy}$ (Fig. 1B, Table $1)$.

The bright red color of non-irradiated meat had been turned brown color especially in samples irradiated at $50 \mathrm{kGy}$, which generally lower its acceptability. Kamarei et al., (1979) reported the generation of free radicals during food processing and storage and upon irradiation the free binding site of myoglobin reacts with such free radicals to form the brown colored metmyoglobin (Giroux et al., 2001). In this respect, consumers consider the visual appearance to be one of the major parameters to judge the quality and acceptability of meat (Demos et al., 1996 and Zhao et al., 1996).

The texture of control non-irradiated or 10 kGy irradiated meat decreased during storage until reached the unacceptable limit at $17^{\text {th }}$ and $52^{\text {nd }}$ days of refrigeration storage respectively, whereas the texture of irradiated. All the investigated bacterial groups were lower than the detectable level of standard plating techniques (2 $\log$ CFU/g) at the first day of treatment with 10kGy gamma irradiation. During storage at $5^{\circ} \mathrm{C}$, the investigated bacterial groups remained under the countable level until the 24th day of storage, and tend to increase by the 32nd day of storage and finally reached $\sim 6 \mathrm{Log} \mathrm{CFU} / \mathrm{g}$ by the $52 \mathrm{nd}$ day with the samples became slimy, off-color and had a sour and putrid odor (Fig. 2b). On the other hand, all the examined bacterial groups of beefsteaks treated with 25 or 50-KGy remained under the detectable level throughout the storage period with acceptable organoleptic parameters.

The obtained results revealed that beef samples treated with $10 \mathrm{kGy}$ had unacceptable organoleptic criteria while the bacterial counts still lower than the level recommended by (Ehioba et al., 1987). This may be due to the action of proteolytic enzymes, which usually survive exposure of up to $10 \mathrm{kGy}$ (Taub et al., 1979). 
Gamma irradiation even at low or medium doses can effectively kill both food borne pathogens and spoilage bacteria that ultimately increase wholesomeness and shelf life of the meat. The effectiveness of gamma irradiation depends on various factors such as the microorganisms itself, type of food, irradiation dose, irradiation temperature, presence of oxygen and water content (Thayer, 1995; Thayer and Boyd, 1995 and Thayer et al., 1995b), with the initial contamination of meat is the determining factor in shelf-life extension produced by gamma irradiation (Dogbevi et al., 1999).

The obtained results indicated that irradiation slightly decreased both moisture and protein content of beef and refrigeration storage induced an additional decrease in moisture content in both irradiated and non-irradiated samples.
Moreover, the decrease in moisture content was dose related and $50 \mathrm{kGy}$ induced the most pronounced change (Fig. 3A, B). The reduction in moisture may be due to improvement of permeability of cells with consequent increase in the fluid exudation (Urbain, 1978) and the decrease in protein may be due to the increase in drip which contain variable amounts of nitrogenious compounds, as well as the breakdown of nitrogenious compounds to form volatile nitrogen (Hafiz, 1973). On the other hand, irradiation slightly increased the ether extractable fat except with $50-\mathrm{kGy}$ treatment (Fig. 3C). These results are constant with the records Mahmoud et al., (1989). Irradiation had no effect on ash content of beef (Fig. 3d). These results were in agreement with Shams El-Din (1984) and Mahmoud et al. (1989).
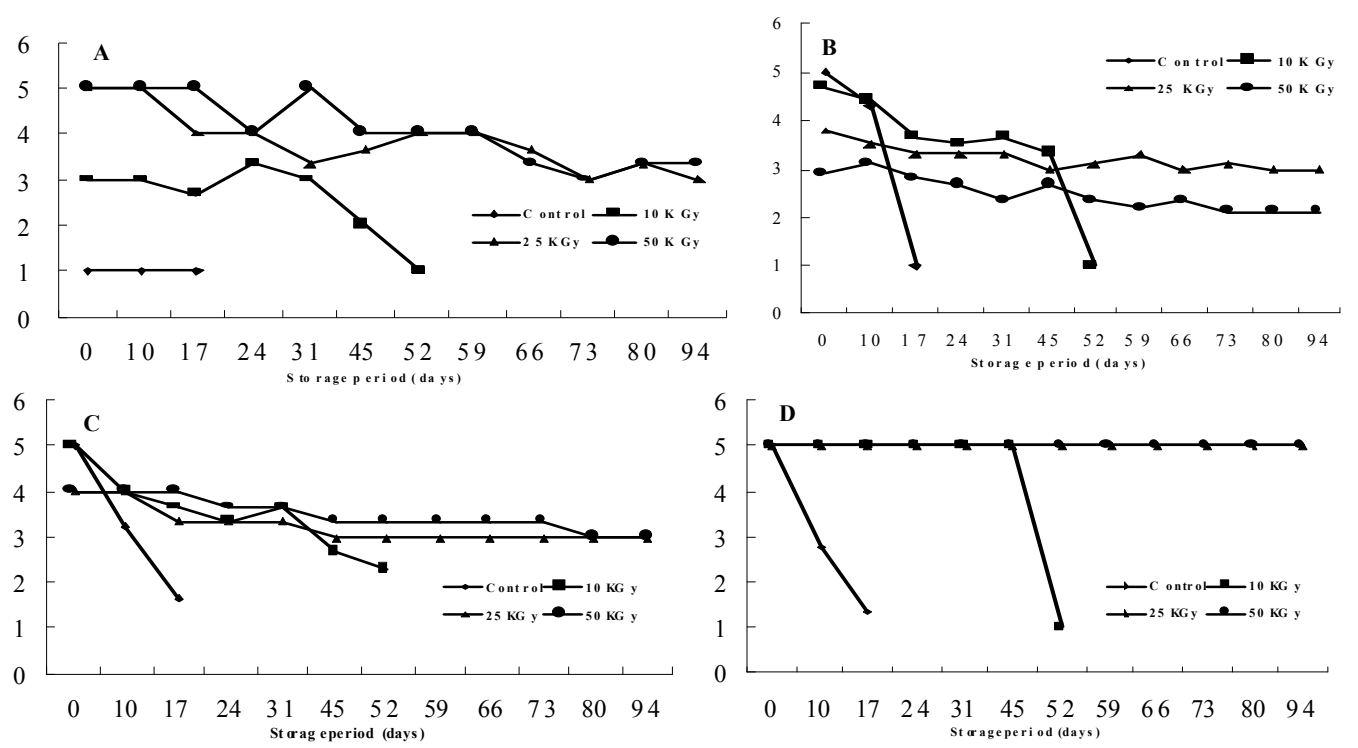

Fig. (1): Effect of gamma irradiation on the organoleptic quality of beef during refrigerated storage. A) Irradiation flavor, B) Color, C) Texture and D) spoilage odor.
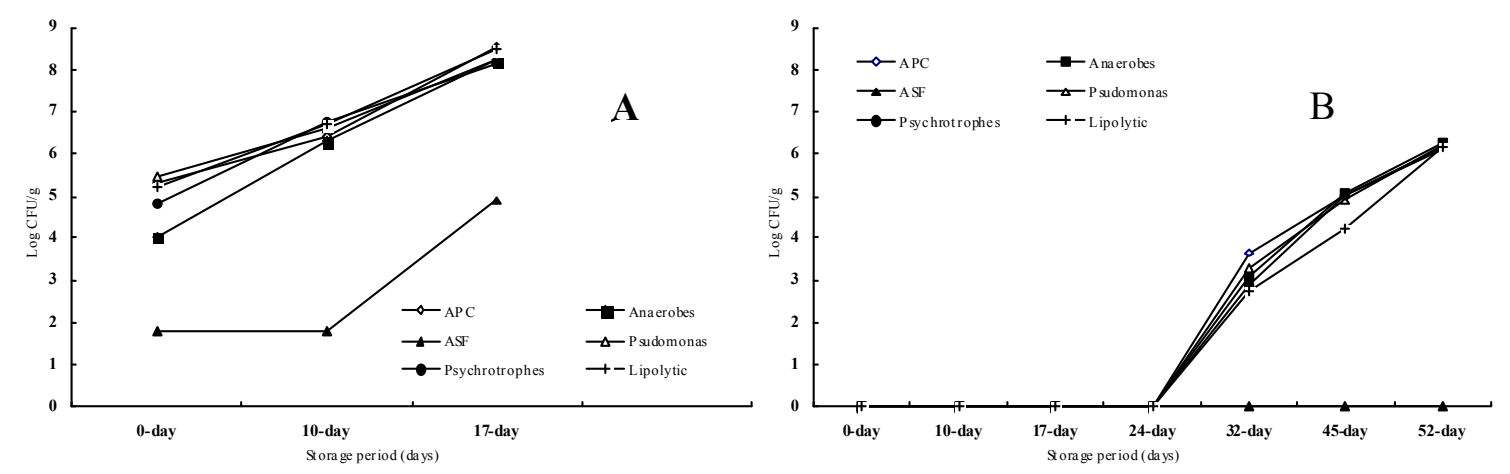

Fig. (2): Bacterial counts ( $\log \mathrm{CFU} / \mathrm{g}$ ) of beef $L$. dorsi muscle during storage at $5^{\circ} \mathrm{C}$. A, control and $B, 10$ KGy treated. 
Table (1): Organoleptic criteria of gamma irradiated beef during storage at $5^{\circ} \mathrm{C}$.

\begin{tabular}{|c|c|c|c|c|c|c|c|c|c|c|c|c|c|c|c|c|}
\hline \multirow{2}{*}{$\begin{array}{c}\text { Storage } \\
\text { (days) }\end{array}$} & \multicolumn{4}{|c|}{ Spoilage off-odor } & \multicolumn{4}{|c|}{ Irradiation flavor } & \multicolumn{4}{|c|}{ Color } & \multicolumn{4}{|c|}{ Texture } \\
\hline & Control & $10 \mathrm{KG}$ & $25 \mathrm{KG}$ & $50 \mathrm{KG}$ & Control & $10 K G$ & $25 K G$ & $50 \mathrm{KG}$ & Control & $10 \mathrm{KG}$ & $25 \mathrm{KG}$ & $50 \mathrm{KG}$ & Control & $10 K G$ & $25 \mathrm{KG}$ & $50 \mathrm{KG}$ \\
\hline $\mathbf{0}$ & 5 & 5 & 5 & 5 & 1 & 3 & 5 & 5 & 5 & 4.7 & 3.8 & 2.9 & 5 & 4.3 & 4 & 3.9 \\
\hline 10 & 2.75 & 5 & 5 & 5 & 1 & 3 & 5 & 5 & 4.3 & 4.4 & 3.5 & 3.1 & 3.25 & 3.66 & 4 & 4 \\
\hline 17 & 1.33 & 5 & 5 & 5 & 1 & 2.66 & 4 & 5 & 1 & 3.66 & 3.33 & 2.8 & 1.66 & 3.33 & 3.33 & 4 \\
\hline 24 & $*$ & 5 & 5 & 5 & $*$ & 3.33 & 4 & 4 & $*$ & 3.5 & 3.33 & 2.66 & $*$ & 3.66 & 3.33 & 3.66 \\
\hline 31 & $*$ & 5 & 5 & 5 & $*$ & 3 & 3.33 & 5 & $*$ & 3.66 & 3.33 & 2.33 & $*$ & 3.33 & 3.33 & 3.66 \\
\hline 45 & $*$ & 5 & 5 & 5 & $*$ & 2 & 3.66 & 4 & $*$ & 3.33 & 3 & 2.66 & $*$ & 2.66 & 3 & 3.33 \\
\hline 52 & $*$ & 1 & 5 & 5 & $*$ & 1 & 4 & 4 & $*$ & 1 & 3.1 & 2.33 & $*$ & 2.3 & 3 & 3.33 \\
\hline 59 & $*$ & $*$ & 5 & 5 & $*$ & $*$ & 4 & 4 & $*$ & $*$ & 3.3 & 2.18 & $*$ & $*$ & 3 & 3.33 \\
\hline 66 & $*$ & $*$ & 5 & 5 & $*$ & $*$ & 3.66 & 3.33 & $*$ & $*$ & 3 & 2.33 & $*$ & $*$ & 3 & 3.33 \\
\hline 73 & $*$ & $*$ & 5 & 5 & $*$ & $*$ & 3 & 3 & $*$ & $*$ & 3.1 & 2.1 & $*$ & $*$ & 3 & 3.33 \\
\hline 80 & $*$ & $*$ & 5 & 5 & $*$ & $*$ & 3.33 & 3.33 & $*$ & $*$ & 3 & 2.1 & $*$ & $*$ & 3 & 3 \\
\hline 94 & $*$ & $*$ & 5 & 5 & $*$ & $*$ & 3 & 3.33 & $*$ & $*$ & 3 & 2.1 & $*$ & $*$ & 3 & 3 \\
\hline
\end{tabular}


Table (2): Bacterial populations ( $\log \mathrm{CFU} / \mathrm{g})$ of control and 10Kgy treated samples during storage at $5^{\circ} \mathrm{C}$.

\begin{tabular}{|c|c|c|c|c|c|c|c|c|c|c|}
\hline \multirow[b]{2}{*}{ Microorganisms } & \multicolumn{3}{|c|}{ Control } & \multicolumn{7}{|c|}{10 kGy } \\
\hline & 0-day & 10-day & 17-day & 0-day & 10-day & 17-day & 24-day & 32-day & 45-day & 52-day \\
\hline APC & 5.33 & 6.43 & 8.5 & $<2$ & $<2$ & $<2$ & $<2$ & 3.64 & 5.02 & 6.12 \\
\hline Staph & 3.97 & 4.56 & 7.28 & $<2$ & $<2$ & $<2$ & $<2$ & $<2$ & 3.84 & 6.05 \\
\hline S.aureus & 2.8 & 3.36 & 4.82 & $<2$ & $<2$ & $<2$ & $<2$ & $<2$ & $<2$ & $<2$ \\
\hline Anaerobes & 4.05 & 6.3 & 8.23 & $<2$ & $<2$ & $<2$ & $<2$ & 3.1 & 5.1 & 6.26 \\
\hline Aerobic spore former & 1.8 & 1.8 & 4.9 & $<2$ & $<2$ & $<2$ & $<2$ & $<2$ & $<2$ & $<2$ \\
\hline Psudomonas & 5.44 & 6.62 & 8.26 & $<2$ & $<2$ & $<2$ & $<2$ & 3.25 & 4.9 & 6.19 \\
\hline Psychrotrophes & 4.82 & 6.75 & 8.14 & $<2$ & $<2$ & $<2$ & $<2$ & 2.9 & 5.02 & 6.09 \\
\hline Lipolytic & 5.23 & 6.7 & 8.47 & $<2$ & $<2$ & $<2$ & $<2$ & 2.75 & 4.24 & 6.13 \\
\hline
\end{tabular}
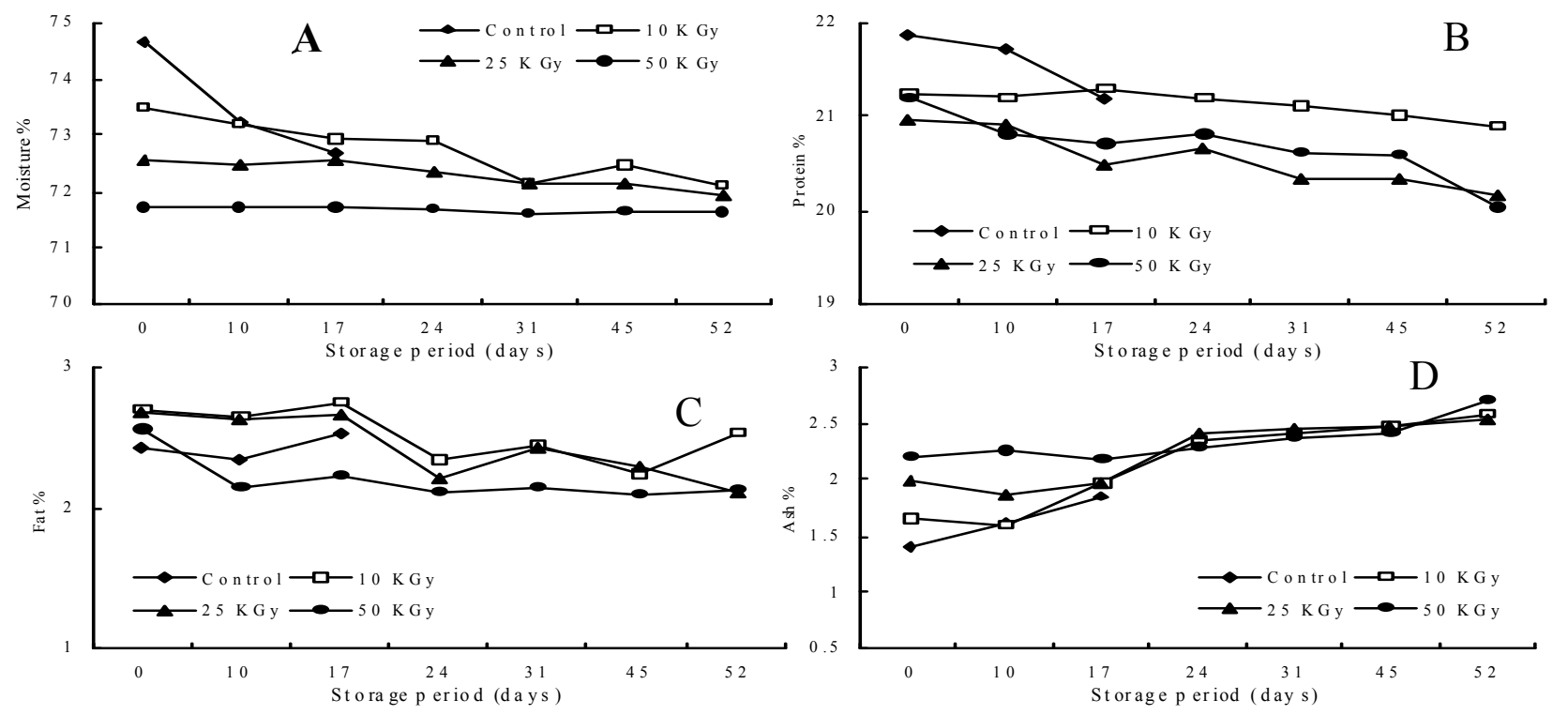

Fig. (3): Effect of gamma irradiation on the proximate chemical analysis of beef during storage at $5^{\circ} \mathrm{C}$. A, moisture; $\mathrm{B}$, protein; C, fat; and $\mathrm{D}$, ash.
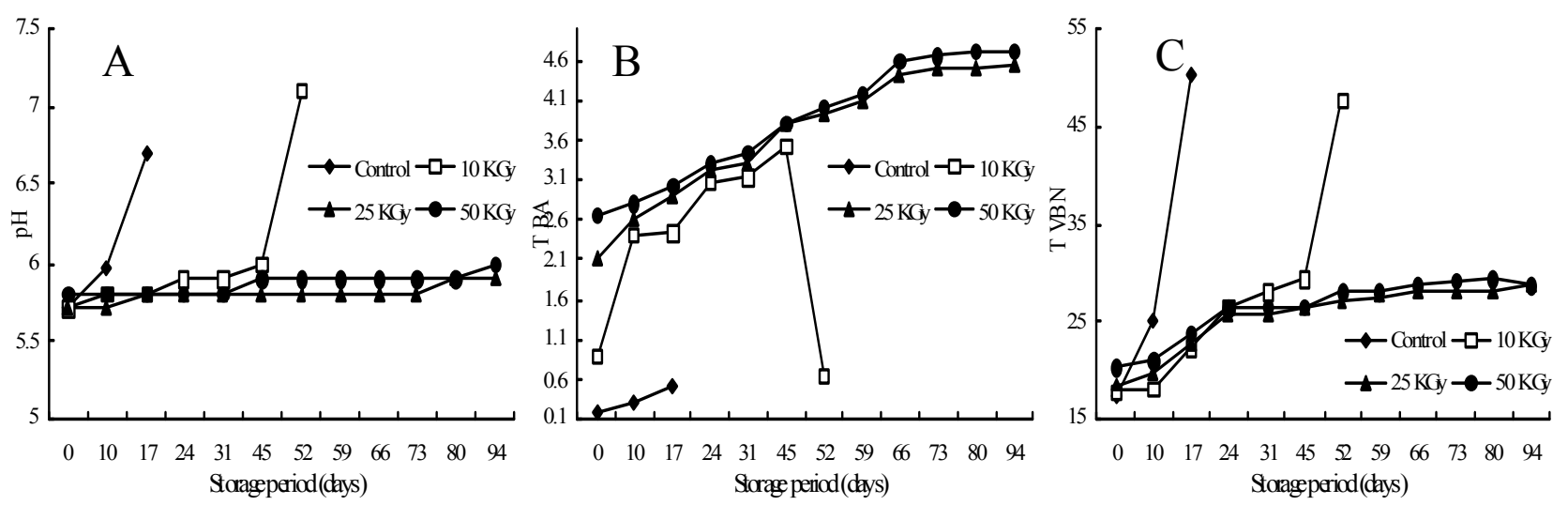

Fig. (4): Effect of gamma irradiation on the deterioration criteria of beef during storage at $5^{\circ} \mathrm{C}$. A, pH; B, Thiobarbituric acid value; $C$, Total volatile base nitrogen 
Table (3): Proximate chemical analysis of gamma irradiated beef during storage at $5^{\circ} \mathrm{C}$.

\begin{tabular}{|c|c|c|c|c|c|c|c|c|c|c|c|c|c|c|c|c|}
\hline \multirow{2}{*}{$\begin{array}{c}\text { Storage } \\
\text { (days) }\end{array}$} & \multicolumn{4}{|c|}{ Moisture \% } & \multicolumn{4}{|c|}{ Protein \% } & \multicolumn{4}{|c|}{ Fat $\%$} & \multicolumn{4}{|c|}{ Ash \% } \\
\hline & Cont. & $10 \mathrm{KGy}$ & $25 \mathrm{KGy}$ & $50 \mathrm{KGy}$ & Cont. & $10 K G y$ & $25 \mathrm{KGy}$ & $50 \mathrm{KG}$ & Cont. & $10 \mathrm{KG}$ & $25 \mathrm{KG}$ & $50 \mathrm{KG}$ & Cont. & $10 \mathrm{KG}$ & $25 \mathrm{KG}$ & $50 \mathrm{KG}$ \\
\hline $\mathbf{0}$ & 74.65 & 73.48 & 72.56 & 71.71 & 21.86 & 21.25 & 20.96 & 21.2 & 2.42 & 2.7 & 2.68 & 2.56 & 1.4 & 1.65 & 1.99 & 2.2 \\
\hline 10 & 73.22 & 73.21 & 72.5 & 71.71 & 21.71 & 21.21 & 20.9 & 20.8 & 2.34 & 2.65 & 2.63 & 2.15 & 1.6 & 1.59 & 1.87 & 2.25 \\
\hline 17 & 72.67 & 72.93 & 72.57 & 71.71 & 21.19 & 21.31 & 20.5 & 20.7 & 2.54 & 2.75 & 2.66 & 2.23 & 1.86 & 1.97 & 1.98 & 2.19 \\
\hline 24 & $*$ & 72.9 & 72.34 & 71.69 & $*$ & 21.19 & 20.65 & 20.81 & $*$ & 2.34 & 2.22 & 2.12 & $*$ & 2.35 & 2.4 & 2.28 \\
\hline 31 & $*$ & 72.16 & 72.15 & 71.6 & $*$ & 21.1 & 20.33 & 20.62 & $*$ & 2.45 & 2.43 & 2.15 & $*$ & 2.4 & 2.45 & 2.38 \\
\hline 45 & $*$ & 72.45 & 72.12 & 71.65 & $*$ & 21 & 20.35 & 20.59 & $*$ & 2.24 & 2.29 & 2.09 & $*$ & 2.47 & 2.47 & 2.42 \\
\hline 52 & $*$ & 72.1 & 71.92 & 71.64 & $*$ & 20.89 & 20.16 & 20.03 & $*$ & 2.54 & 2.12 & 2.13 & $*$ & 2.58 & 2.53 & 2.71 \\
\hline
\end{tabular}

*Samples spoiled

Table (4): Deterioration criteria of gamma irradiated beef during storage at $5^{\circ} \mathrm{C}$.

\begin{tabular}{|c|c|c|c|c|c|c|c|c|c|c|c|c|}
\hline \multirow{2}{*}{$\begin{array}{c}\text { Storage } \\
\text { (days) }\end{array}$} & \multicolumn{4}{|c|}{ TBA values (mg/kg) } & \multicolumn{4}{|c|}{ TVB-N values (mg/100g) } & \multicolumn{4}{|c|}{ pH values } \\
\hline & Control & 10 kGy & 25 kGy & 50 kGy & Control & 10 kGy & 25 kGy & 50 kGy & Control & 10 kGy & $25 \mathrm{kGy}$ & 50 kGy \\
\hline $\mathbf{0}$ & 0.19 & 0.89 & 2.12 & 2.65 & 17.36 & 17.9 & 18.48 & 20.3 & 5.7 & 5.7 & 5.7 & 5.8 \\
\hline 10 & 0.28 & 2.4 & 2.63 & 2.8 & 25.2 & 18.2 & 19.6 & 21 & 5.97 & 5.8 & 5.7 & 5.8 \\
\hline 17 & 0.51 & 2.42 & 2.9 & 3.02 & 50.2 & 22.4 & 22.8 & 23.8 & 6.7 & 5.8 & 5.8 & 5.8 \\
\hline 24 & $*$ & 3.07 & 3.23 & 3.3 & $*$ & 26.6 & 25.8 & 26.3 & $*$ & 5.9 & 5.8 & 5.8 \\
\hline 31 & $*$ & 3.12 & 3.29 & 3.43 & $*$ & 28 & 25.8 & 26.6 & $*$ & 5.9 & 5.8 & 5.8 \\
\hline 45 & $*$ & 3.5 & 3.8 & 3.8 & $*$ & 29.4 & 26.6 & 26.6 & $*$ & 6 & 5.8 & 5.9 \\
\hline 52 & $*$ & 0.64 & 3.91 & 4.02 & $*$ & 47.6 & 27.2 & 28 & $*$ & 7.1 & 5.8 & 5.9 \\
\hline 59 & $*$ & $*$ & 4.1 & 4.19 & $*$ & $*$ & 27.6 & 28 & $*$ & $*$ & 5.8 & 5.9 \\
\hline 66 & $*$ & $*$ & 4.4 & 4.6 & $*$ & $*$ & 28 & 28.6 & $*$ & $*$ & 5.8 & 5.9 \\
\hline 73 & $*$ & $*$ & 4.5 & 4.66 & $*$ & $*$ & 28 & 29.2 & $*$ & $*$ & 5.8 & 5.9 \\
\hline 80 & $*$ & $*$ & 4.52 & 4.7 & $*$ & $*$ & 28 & 29.4 & $*$ & $*$ & 5.9 & 5.9 \\
\hline 94 & $*$ & $*$ & 4.53 & 4.7 & $*$ & $*$ & 28.8 & 28.8 & $*$ & $*$ & 5.9 & 6 \\
\hline
\end{tabular}



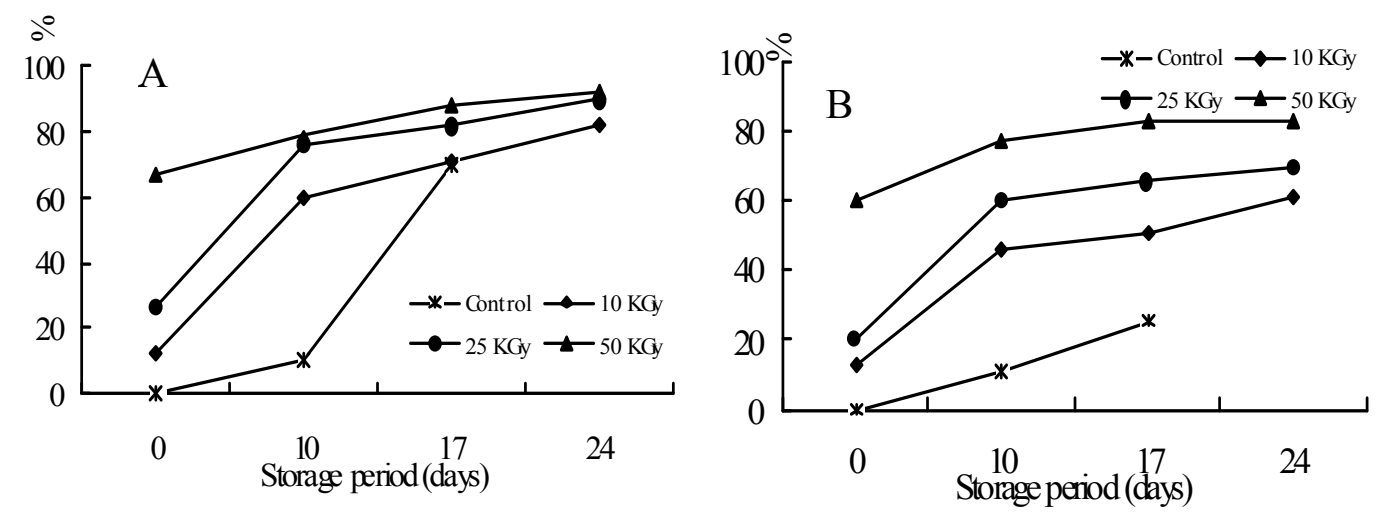

Fig. (5): Percentage loss of vitamin in gamma irradiate beef $L$. dorsi muscle during storage at $5^{\circ} \mathrm{C}$. A, thiamin; $\mathrm{B}$, riboflavin.

Table (5): Losses of thiamin and riboflavin of gamma irradiated beef during storage at $5^{\circ} \mathrm{C}$.

\begin{tabular}{ccccccccc}
\hline & \multicolumn{8}{c}{ Percentage of losses } \\
\cline { 2 - 9 } Storage (days) & \multicolumn{9}{c}{ Thiamin } & \multicolumn{5}{c}{ Riboflavin } \\
\cline { 2 - 9 } & Control & $\mathbf{1 0}$ kGy & $\mathbf{2 5}$ kGy & $\mathbf{5 0}$ kGy & Control & $\mathbf{1 0}$ kGy & $\mathbf{2 5}$ kGy & $\mathbf{5 0}$ kGy \\
\hline $\mathbf{0}$ & 0 & 12 & 26.4 & 67.5 & 0 & 12.76 & 26.3 & 59.6 \\
$\mathbf{1 0}$ & 9.8 & 60.3 & 76.2 & 78.5 & 10.72 & 46.24 & 60.19 & 76.77 \\
$\mathbf{1 7}$ & 70.2 & 71.3 & 81.8 & 88.6 & 25.26 & 50.53 & 65.07 & 82.77 \\
$\mathbf{2 4}$ & $*$ & 82.6 & 90.1 & 92.4 & $*$ & 60.9 & 69.4 & 82.83 \\
\hline
\end{tabular}

*Samples spoiled

The data illustrated in Fig. (4A) showed that irradiation at 10,25 or $50 \mathrm{kGy}$ did not cause significant changes in $\mathrm{pH}$ values; however, there was a slight increase in $\mathrm{pH}$ values during refrigeration storage. The $\mathrm{pH}$ values of control and $10 \mathrm{kGy}$ treated samples reached 6.7 and 7.1 after 17 and 52 days of storage; respectively with apparent signs of spoilage. While the $\mathrm{pH}$ values of samples treated with 25 and $50 \mathrm{kGy}$ remained within the acceptable values until the end of storage period. Lebepe et al., (1990) and Fox et al., (1995) reported that irradiation did not induce significant change in $\mathrm{pH}$ of beef, lamb, pork, and turkey after treatment with irradiation doses up to 9.4. It is evident from Fig. (4B) that high dose of gamma irradiation caused a pronounced increase in TBA-values, which was dose dependant. Moreover, TBA value was also increased during refrigeration storage at $5^{\circ} \mathrm{C}$. Generally, irradiation increased TBAvalues in meat, which may be explained by the fact that autoxidation of fat is accelerated when oxygen is present during or after irradiation as a result of initiation of lipid oxidation (Nawar, 1985). There was a decline in TBA-value of beef irradiated at $10 \mathrm{KGy}$ by the end of storage period, which might be due to breakdown of hydroperoxides and formation of secondary products of lipid oxidation, which do not react with the TBA reagent, or the reaction of malonaldehyde with protein (Melton, 1983). Fig. (4C) showed that irradiation cause slight increase in TVB-N as compared with the nonirradiated samples. This slight increase may be due to formation of protein degradation products as carbonyl groups, ammonia, hydrogen peroxide and organic peroxide (Delincee, 1982). By $17^{\text {th }}$ day, the TVB-N of unirradiated samples reached $50.2 \mathrm{mg} / 100 \mathrm{~g}$ with apparent signs of spoilage, while in beef irradiated with $10 \mathrm{kGy}$, it reached $47.6 \mathrm{mg} / 100 \mathrm{~g}$ by the $52^{\text {nd }}$ day. In samples irradiated at 25 and $50 \mathrm{kGy}$, the TVB$\mathrm{N}$ remained within acceptable limit (30 $\mathrm{mg} / 100 \mathrm{~g}$ ) for up to 4 months of refrigerated storage at $5^{\circ} \mathrm{C}$. Paul et al., (1990) reported that TVB-N values increased in unirradiated lamb meat chunks and meat mince to $35 \mathrm{mg} / 100 \mathrm{~g}$ within 2 weeks corresponding to poor scores for sensory evaluation. Moreover, after 4 weeks, the values were as high as $60 \mathrm{mg} / 100 \mathrm{~g}$ compared to $35 \mathrm{mg} / 100 \mathrm{~g}$ for samples irradiated at $1.0 \mathrm{kGy}$, while no increase was detected in TVB-N values for samples irradiated at $2.5 \mathrm{kGy}$. It has been well established that meat is a significant source 
of thiamin and it is the most sensitive vitamin to irradiation (Diehl, 1995). Thiamin losses were $12.8,26.4$ and $67.5 \%$ of non-irradiated samples after treatments with 10,25 , and 50 kGy respectively, compared to $12.76,26.3$ and 59.6 $\%$ for riboflavin. Storage at $5^{\circ} \mathrm{C}$ resulted in much more loss of both vitamins in both irradiated and non-irradiated meat, and the loss of riboflavin was lower than that of thiamin (Fig. 5). AlKahtani et al., (1996) and Giroux and Lacroix (1998) found that riboflavin is relatively stable to irradiation. However, Ziporin et al., (1957) found that irradiation of beef samples containing $1.86 \mu \mathrm{g}$ riboflavin/g at 28 and $56 \mathrm{kGy}$ resulted in retention of about 1.76 and $1.79 \mu \mathrm{g} / \mathrm{g}$ of riboflavin after treatment respectively. The loss of thiamin as a result of irradiation may be attributed to oxidative damage, destruction of its pyrimidin ring, and loss of the amino group (Giroux and Lacroix, 1998).

\section{References}

Abu-Tarboush, H. M.; Al-Kahtani, H. A.; Atef, M. A.; Abou-Arab, A. A.; Bajaber, A. S. and El-Mojaddadi, M. A. (1997): Sensory and microbial quality of chicken as affected by irradiation and post-irradiation storage at $4.0^{\circ} \mathrm{C}$. J. Food Prot., 60: 761.

Ahn, D. U.; Nam, K. C.; Du. M. and Jo, C. (2001): Volatile production in irradiated normal, pale soft exudative (PSE), and dark firm dry (DFD) pork under different packaging and storage conditions. Meat Sci., 57: 419.

American Public Health Association (APHA) (1992): Compendium of Methods for Microbiological Examination of Food. $3^{\text {rd }}$ ed., Washington DC, USA.

Al-Kahtani, H. A.; Abu-Tarboush, H. M.; Bajaber, A. S.; Atia. M.; Abou-Arab, A. A. and El-Mojaddidi, M. A. (1996): Chemical changes after irradiation and postirradiation storage in Tilapia and Spanish mackerel. J. Food Sci., 61: 729 .

Chase, G. W.; Landen, W. O. and Soliman, G. M. (1993): Method modification for liquid chromatographic determination of thiamin, riboflavin, and pyridoxine in medical foods. J. AOAC Int., 76: 1276.

Cousin, M. A.; Jay, J. M. and Vasavada, P. (1992): Psychrotrophic microorganisms. In: Compendium of Methods for the Microbiological Examination of Foods, $3^{\text {rd }}$ ed. C. Vanderzant and D. F. Splittstoesser, ed. Am. Pub. Health Assoc., Washington, DC. pp. 75-77.

Delincee, H. (1982): An introduction to the radiation chemistry of major food component, IFFIT-training Course, Bundes Forshung Für Ernahrung, D-7500 Karlsruhe, 1-107. Demos, B. P.; Gerrard, R. W.; Mandigo, X. and Tan, J. (1996): Mechanically recovered neck bone lean and ascorbic acid improve color stability of ground beef patties. J. Food Sci., 61: 656.

Diehl, J. F. (1995): Radiological and Toxicological Safety of Irradiated Foods, Safety of Irradiated Foods, $2^{\text {nd }}$ ed. Revised and expanded. Marcel Dekker. New York, 6: 173.

Dogbevi, M. K.; Vachon, C. and Lacroix, M. (1999): Physicochemical and microbiological changes in irradiated fresh pork loins. Meat Sci., 51: 349.

Ehioba, R. M.; Kraft, A. A.; Molins, R. A.; Walker, H. W.; Olson, D. G.; Subbaraman, G. and Skowronski, R.
P. (1987): Effect of low dose (100 krad) gamma radiation on the microflora of vacuum-packaged ground pork with and without added sodium phosphates. J. Food Sci., 52: 1477,1505

Food and Agriculture Organization "FAO" (1986): Food and Nutrition paper. Manuals of Food Quality Control. 8. Food Analysis: quality, adulteration, and tests of identity. Rome, Italy.

Fox, J. B.; Lakritz, L.; Hampson, J.; Richardson, R.; Ward, K. and Thayer, D. W. (1995): Gamma irradiation effects on thiamin and riboflavin in beef, lamb, pork, and turkey. J. Food Sci., 60: 596.

Fu, A.; Sebranek, J. G. and Murano, E. A. (1995): Survival of Listeria monocytogenes, Yersinia enterocolitica and Escherichia coli $\mathrm{O} 157: \mathrm{H} 7$ and quality changes after irradiation of beefsteaks and canned beef. J. Food Sci., 60: 972.

Giroux, M, and Lacroix, M. (1998): Nutritional adequacy of irradiated meat: A review. Food Res. Int., 31: 257.

Giroux, M.; Ouattara, B.; Yefsah, R.; Smoragie, W.; Saucier. L. and Lacroix, M. (2001): Combined effect of ascorbic acid and gamma irradiation on microbiological and sensorial characteristics of beef patties during refrigerated storage. J. Agric. Food Chem., 49: 919.

Hafiz, N. E. (1973): Chemical and technological changes of Aswan Bolti fish during frozen state. M Sc. Thesis, Fac. Agric. Al-Azhar Univ., Egypt.

Joint FAO/IAEA/WHO Expert Committee (1981): Wholesomeness of irradiated food. Geneva, World Health Organization (WHO Technical Report Series No. 659).

Kamarei, A. R.; Karel, M. and Wiericki, E. (1979): Spectral studies on the role of ionizing radiation in color changes of radappertized beef, J. Food Sci., 44: 25.

Kielwein, G. (1969): Ein Nahrboden zur selective zuchtung von Pseudomonaden and Aeromonaden. Arch. F. Lebensmittelhyg, 20: 131-133.

Lake, D. E.; Bernard, D. T. and Kautter, D. A. (1992): Mesophilic anaerobic sporeformers. In: "Compendium of Methods for the Microbiological Examination of Foods", 3rd ed. C. Vanderzant and D. F. Splittstoesser, ed. American Public Health Association, Washington, DC. pp. 275-289.

Lakritz, L.; Fox, J. B. Jr.; Hampson, J.; Richardson, R.; Kohout, K. and Thayer, D. W. (1995): Effects of gamma radiation on level of $\alpha$-tocopherols in red meats and turkey. Meat Sci., 41: 261

Lebepe, S.; Molins, R. A.; Charoen, S. P.; Farrariv, H. and Skowronski, R. P. (1990): Changes in microflora and other characteristics of vacuum-packaged pork loins irradiated at 3-kGy . J Food Sci., 55: 918.

Mahmoud, A. A.; Shalaby, M. T.; Doma, M. B.; Hussein, M. A. and Emam, O. A. (1989): Effect of gamma irradiation and cold storage at $4 \pm 1{ }^{\circ} \mathrm{C}$ on components of buffalo meat. Egypt. J. Rad. Sci. Appl., 6: 73

Melton, S. (1983): Methodology for following lipid oxidation in muscle foods. Food Technol., 37: 105.

Nawar, W. W. (1985): Lipids. In: Food Chemistry O. R. Fennema (ed.), Marcel Dekker Inc., New York. pp. 139244.

Paul, P.; Venugopal, V. and Nair, P. M. (1990): Shelf life enhancement of lamb meat under refrigeration by gamma irradiation. J. Food Sci., 55: 865.

Ronald, S. K. and Ronald, S. (1991): Pearson's Composition and Analysis of Foods. $9^{\text {th }}$ ed. Longman Scientific and Technical., England. 
Shams El-Din, N. M. (1984): Studies on changes in certain characteristics on meat subjected to radiation, Ph. D., Thesis, Fac. Agric., Ain-Shams Univ. Egypt.

Simic, M. G. (1983): Radiation Chemistry of Water Soluble Food Components, In: Josephson, E. S. and Peterson, M. S. (ed.), Preservation of Food by Ionizing Radiation. CRC Press, Inc. Boca Raton, FL. p. 1-73.

Smith, J. L. and Hass, M. J. (1992): Lipolytic Microorganisms. In: Compendium of Methods for the Microbiological Examination of Foods. $3^{\text {rd }}$ ed. C. Vanderzant and D. F. Splittstoesser, ed. Am. Pub. Health Assoc., Washington, DC. pp. 75-77.

Stevenson, K. E. and Segner, W. P. (1992): Mesophilic Aerobic Sporeformers. In: Compendium of Methods for the Microbiological Examination of Foods. $3^{\text {rd }}$ ed. C. Vanderzant and D. F. Splittstoesser, ed. American Public Health Association, Washington, DC. pp. 265-274.

Stevenson, M. H. (1994): Nutritional and other implications of irradiation meat. Proc. Nut. Soc., 53: 317. Sudarmadji, S. and Urbain, W. M. (1972): Flavor sensitivity of selected animal protein foods to gamma radiation. J. Food Sci., 37: 671.

Swanson, K. M. J.; Busta, F. F.; Peterson, E. H. and Johnson, M. G. (1992): Colony Count Methods. In: Compendium of Methods for the Microbiological Examination of Foods. $3^{\text {rd }}$ ed. C. Vanderzant and D. F. Splittstoesser, ed. American Public Health Association, Washington, D.C.

Taub, I. A.; Robbins, F. M.; Simic, M. G.; Walker, J. E. and Wierbick, E. (1979): Effects of irradiation on meat proteins. Food Technol., 33: 184.
Thayer, D. W. (1993): Extending shelf life of poultry and red meat by irradiation processing. J. Food Prot., 56: 831.

Thayer, D. W. (1995): Use of irradiation to kill enteric pathogens on meat and poultry. J. Food Safety, 15: 181.

Thayer, D. W. and Boyd, G. (1995): Radiation sensitivity of Listeria monocytogenes on beef as affected by temperature. J. Food Sci., 60: 237.

Thayer, D. W.; Boyd, G. and Huhtanen, C. N. (1995): Effects of ionizing radiation and anaerobic refrigerated storage on indigenous microflora, Salmonella, and Clostridium botulinum type, A and B in vacuum-canned, mechanically deboned chicken meat. J. Food Prot. 58: 752.

Thayer, D. W.; Boyd, G. and Jenkins, R. K. (1993): Low dose gamma irradiation and refrigerated storage in vacuum affect microbial flora of fresh pork. J. Food Sci., 58: 717.

Urbain, W. M. (1978): Irradiation of meats and poultry. Food Irrad. Inform., 8: 14

Urbain, W. M. (1986): Biological effects of ionizing radiation. In Food Irradiation, Academic Press INC, Orlando, San Diego, NY. pp. 83-117.

Zhao, Y.; Sebranek, J. G.; Dickson, J. and Lee, M. (1996): Bacteriological, physicochemical, and sensory quality of fresh pork chops treated with low-dose irradiation and modified-atmosphere packaging. J. Food Prot., 59: 493.

Ziporin, Z. Z.; Kraybill, H. F. and Thach, H. J. (1957): Vitamin content of foods exposed to ionizing radiation. J. Nutri., 63: 201. 